\title{
SCHELLING E A CONSTITUIÇÃO DA ESTÉTICA MUSICAL
}

Fernando de Moraes BARROS ${ }^{1}$

- RESUMO: O presente artigo conta investigar o processo de constituição da estética musical a partir da teoria da arte elaborada por F. W. J. von Schelling. Para tanto, espera-se mostrar a maneira pela qual o filósofo alemão procura redimensionar as bases que davam sustentação à chamada estética sistemática para, a partir de uma ponderação extremamente inovadora, caracterizar a música como um objeto original de saber.

- PALAVRAS-CHAVE: Schelling; Kant; arte; música; ritmo; modulação; melodia.

\section{Na arte, a filosofia}

Pode-se afirmar, em linhas gerais, que a vertente crítica da filosofia clássica alemã data do momento em que, por obra da "Dialética transcendental" (Kant, 1974, p.308; B 350/A 293-294), Kant procura levar a cabo um exame radical dos mais insuspeitos objetos da metafísica dogmática. Porque tal procedimento implica a análise livre e laica de supremas referências especulativas, a própria vocação filosófica para as grandes explicações do mundo e da natureza dele não sairá incólume. Desprezando o fato de que ao homem é impossível ultrapassar seu sistema perceptivo, postulou-se reiteradamente um modo universal de conhecimento, tido como o único a permitir o acesso a uma estrutura objetiva da realidade. Incondicional, a busca por princípios logo cedeu terreno à idéia de um sistema completo dos saberes, e, com isso, perdeu-se de vista que tal totalidade é somente um ideal para

1 Professor Adjunto do Departamento de Filosofia e Ciências Humanas da Universidade Estadual de Santa Cruz-UESC/BA. Artigo recebido em set/07 e aprovado em dez/07. 
efigiar a somatória de determinadas perspectivas. Afinal de contas, como dirá o célebre filósofo de Königsberg: "A filosofia é uma simples idéia de uma ciência possível que, in concreto, não é dada em parte alguma" (idem, v.2, p.700; B 867). Reconhecido então o caráter fatalmente limitado de todo conhecimento, é natural que a ponderação filosófica acerca da música passe, também ela, a se interrogar em termos de suas condições de possibilidade. Cumpre, pois, indagar: por que, depois da filosofia crítica, a pergunta pela "essência" da arte dos sons? Um autor ensaiou uma resposta a essa questão, pela primeira vez, na esteira do kantismo: F. W. J. von Schelling.

Longe de ser acidental, a escolha de tal referencial artístico orienta-se por um movimento positivo de superação, já que, ao operar um redimensionamento da assim chamada estética sistemática, Schelling espera conceder à música, como iremos ver, um papel filosófico inédito. Concebida sob a idéia de que não há uma efetiva separação entre espírito e natureza, a arte mesma deixará de ser, em tal registro, apenas uma esfera entre as outras. Mais do que um simples repertório de temas, ela irá tomar sobre si uma tarefa de fôlego: tornar-se o organon crítico da filosofia. Isso porque, para o autor da Filosofia da arte, é precisamente pela reflexão estética que se dá a dissolução dos grilhões que, em rigor, prendem a consciência filosófica à exibição unilateral dos pares universal/particular, real/ideal, sujeito/objeto etc. Essa esperança de unir os opostos se assenta numa reflexão que detecta entre o particular e o universal somente uma diferença gradativa, pressupondo, do ponto de vista qualitativo, uma indelével identidade estrutural sua "formação-em-um" [Einbildung]. Caudatários dessa visão, sujeito e objeto também surgem, no limite, como noções indissolúveis, que irrompem em potências diferentes nas produções artísticas individuais, mas que, em sua convergência interna, tomam parte simultaneamente de uma só meta obra de arte orgânica e coletiva. Conjunção que irá desaguar, não por acaso, numa luta sem descanso contra a oposição dos contrários, cuja expressão ganha relevo, por exemplo, no seguinte aceite schellingiano: "na matéria da arte nenhuma oposição é pensável a não ser uma oposição formal" (Schelling, 2001, p.109).

É bem verdade que, em termos de sua efetividade histórica, a interdependência entre arte e filosofia não é algo totalmente evidente. Para a tradição, o filósofo é aquele que, de raciocínio em raciocínio, torna "pensável" tudo o que o rodeia, acreditando obter um caminho retilíneo rumo à verdade depois de ter dissipado as sombras da paixão e do sentimento. Outro é o caminho trilhado pelo artista. Inspirado pelas Musas, ele abre mão desse processo depurativo, voando para além do saber exclusivamente conceitual. Intuitivo, o seu conhecimento decerto parte das percepções sensíveis elementares, mas, no fundo, pretende ultrapassar a maneira comum de sentir e pensar, já que acredita atingir um nível onde o discernimento é um 
modo quase "simpático" de apreender e representar os objetos. Exposto a toda sorte de estimulação, o artista faria as vezes daquele "sofista admirável" que, munido de um espelho, termina por refletir infielmente todas as construções de mundo, tornando a fabricar tudo e vitimando a todos com suas reproduções. E, nesse sentido, para trazer à tona a apreciação condenatória de Platão, ele não passaria de "um charlatão e imitador", alguém que tomamos por sábio universal apenas pelo fato de sermos incapazes "de fazer a distinção entre o conhecimento, a ignorância e a imitação" (Platão, 2000, p.438; 598d)

Instância que habitualmente designa aquilo que é confuso e obscuro, a sensibilidade artística seria, então, sempre objeto de suspeita. Mas que espécie de ideal de inteligibilidade é esse, em virtude do qual se pretende expor acintosamente ao vexame o modo artístico de ser e pensar? Por que só o pensamento supra-sensível faz jus às credenciais filosóficas? Não teria o sensível um salvo-conduto ao menos no interior de uma teoria "inferior" do conhecimento? A esse protesto de consideração somos conduzidos pelo próprio Baumgarten que, há tempos, já se insurgia como patrono da moderna estética sistemática: "Agora, conhecemo-la [a estética] como uma ciência, e, por conseguinte, deve-se poder dizer a seu respeito tudo aquilo que se diz acerca de uma ciência: ela deve ter fundamentos seguros [sie muss gewisse Gründe haben]. Suas conclusões devem certamente ser deduzidas desses fundamentos seguros" (Baumgarten, 1983, p.82).

É certo que, assegurada a diferença específica do saber sensível, as conclusões de tal ciência deverão ostentar apenas uma clareza extensiva sobretudo se se entender por isso a renúncia ao tradicional critério de clareza e distinção, por meio do qual se torna possível distinguir substâncias no sentido epistemológico do termo, quer dizer, naturezas simples e absolutas. Mas Baumgarten, como se sabe, tratará de retirar dessa restrição uma elevada positividade. Afinal, a confluência de marcas e imagens sensíveis não trará, para o esteta, os mesmos efeitos corrosivos que tendem a apresentar àquele que, para instaurar o campo da representação e descrever as determinações dos objetos, tem de se precaver da volubilidade dos sentidos. Vigora, aqui, a idéia de que o conhecimento sensível adquire o vértice de sua clareza e o ápice de sua completude em seu próprio meio. Bastando-se no próprio chão em que pisa, a estética teria como objetivo o aperfeiçoamento do sensível como tal. Tanto é assim que se diz: "Essa estética diferencia-se da lógica por ter, como seu objeto, o conhecimento sensível, as forças cognoscitivas inferiores" (ibidem). Como teoria do conhecimento sensível, a estética não poderia, pois, permanecer insensível aos desenvolvimentos da própria sensibilidade, cabendo ao esteta regular a claridade sob a qual as ditas "faculdades inferiores" retomam, a seu modo, unidade e coesão. 
Não é isso, porém, que irá dar forma e conteúdo à ponderação schellingiana. Ao autor da Filosofia da arte não interessa elevar o sensível ao estatuto de saber para, a partir de uma revalorização das faculdades humanas, elaborar e afirmar uma teoria específica. Fruto de uma nova e mais visceral intuição da arte, seu empreendimento não espera multiplicar um corpo de significações já disponível. Tanto é assim que, tomando distância das disciplinas regionais recém-constituídas, ele dirá: "Peço-lhes sobretudo para não confundir essa ciência da arte com nada daquilo que até agora se apresentou sob esse nome, ou sob um outro nome qualquer, tal como estética ou teoria das belas-artes e belas ciências" (Schelling, 2001, p.24). ${ }^{2}$ Não que as investigações particulares - certamente fecundas - devam ser preteridas ou subutilizadas. Renunciando à investigação do universal, elas orientariam na delimitação de conceitos específicos, localizando suas semelhanças e dessemelhanças, apontando para os débitos e créditos que entre eles se estabelecem. Mas porque acredita que "a filosofia da arte deve ser = construção da arte" (idem, p.27) e que, portanto, a produção estética pode visar ao universal por meio de seus próprios recursos, Schelling julga que cabe à arte a tarefa de constituir aquilo a propósito de que fala o esteta. Não é a primeira que deve ser mutilada em termos de sua integridade para, aí então, enquadrar-se ou submeter-se à significação imposta pelo segundo. Lá onde a ponderação estética é tratada como particular, onde se lhe apregoam códigos exclusivos de leitura, ela se perde de si mesma e, nesse sentido, converte-se em "teoria". A esse respeito, diz-se ainda: "Tal teoria poderia sem dúvida, tomar de novo emprestado seus princípios da filosofia (...) mas precisamente porque apenas toma emprestado, ela não é filosofia" (idem, p.30).

Com isso, a conseqüência a que Schelling espera conduzir-nos é a de que a arte também estabelece, a partir de um horizonte hermenêutico de intensa prodigalidade, um vínculo umbilical com a filosofia. Isso porque, sob sua égide, cumpre-se a construção, não da arte como arte, mas, como dirá o filósofo, a construção do "universo na figura da arte" (ibidem). Mas, já que a possibilidade de lograrmos tal visão de conjunto não é algo patente

2 Para frisar a vocação "holística" da qual a filosofia da arte deve, a seu ver, investir-se, Schelling irá fazer do não-pertencimento às teorias já constituídas a própria marca do sistema que conta apresentar. Nesse sentido, lê-se: "Antes de Kant, toda doutrina da arte na Alemanha era uma mera descendente da Estética de Baumgarten - pois foi ele quem usou essa expressão pela primeira vez. No período imediatamente anterior a Kant, quando popularidade superficial e empirismo eram dominantes na filosofia, foram elaboradas as conhecidas teorias das belas-artes e belas ciências (...) Procurava-se explicar o belo pela psicologia empírica, e em geral os milagres da arte eram tratados mais ou menos da mesma esclarecedora e degeneradora com que na mesma época se tratavam as histórias de fantasmas e outras superstições" (Schelling, 2001, p.25). 
nem imediato, o acalentado exame não poderá deter-se aí. Que a filosofia da arte seja a exposição do universo na forma da arte, eis algo que ainda não nos fornece, por si só, uma "Idéia completa". Para tanto, cabe observar, como condição de compreensibilidade, o "modo de construção necessário a uma filosofia da arte" (ibidem).

Que tal modo de construção presente no umbral da Filosofia da arte não segue as diretrizes da assim chamada estética dos efeitos, eis o que também salta aos olhos de quem nela se embrenha: "É tido como grosseiro e inculto aquele que em parte alguma se deixa influenciar pela arte e não quer experimentar seus efeitos. Mas é igualmente grosseiro (...) tomar por efeitos da arte como tal as emoções meramente sensíveis, os afetos e a satisfação sensível que as obras de arte suscitam" (idem, p.22). Contra tal atitude, objeta-se que a simples satisfação sensível, ao contrário do que nos revela o imediatismo do gosto, não assegura a presença diáfana e clarividente, ao sujeito da fruição estética, do objeto artístico. A primazia da arte não residirá, aqui, na comoção que algumas obras isoladas podem ocasionar, mas no fato de que, na intuição do belo, se nos apresenta uma totalidade da qual não se pode abrir mão sem prejudicar, com isso, as condições mesmas de incremento e sustentação da beleza: "O que comove são talvez as belezas isoladas, mas na verdadeira obra de arte não há beleza isolada, somente o todo é belo" (ibidem).

Segundo essa perspectiva, a dimensão efetivamente artística permanece obstruída àquele que, nem por um instante, consegue participar ativamente de seus próprios acontecimentos sensoriais. Para Schelling, o todo não se deixa descerrar em sua plenitude se não se distinguir a excitação cega e desgarrada de uma contemplação que é, ao mesmo tempo, "passiva e ativa, arrebatada e refletida". E, se se trata de criar anticorpos contra a fruição passiva, que em momento algum visa à reconstrução dos princípios que se tornaram operatórios numa dada obra, uma moderada dose de formalismo talvez seja bem-vinda - inoculando-nos, quiçá, com a pergunta pelos meios dos quais o artista se serviu para suscitar determinadas paixões e manipular estados internos de tensão. Afinal: "Quantos não estiveram diante de um palco sem se perguntar, uma vez sequer, quantas condições são requeridas mesmo para uma apresentação teatral apenas modernamente bem feita! Quantos não sentiram a nobre impressão de uma bela arquitetura, sem serem tentados a indagar acerca dos fundamentos da harmonia que tão de perto lhes falava!" (ibidem).

Pressupondo alguma intimidade com tais princípios construtivos, o conhecimento geral da arte também não dispensará uma diligência abrangente e multifária do espírito, que se esforçará para deslindar a trama labiríntica das formas artísticas sem romper o vasto tecido que elas constituem: "Reconheço muito bem o quanto é difícil adquirir mesmo os co- 
nhecimentos mais gerais sobre cada parte deste que é o mais infinito de todos os domínios" (idem, p.26). Ciente do artesanato compositivo à base das criações, Schelling não conta enaltecer a genialidade sem atinar, ao mesmo tempo, com a fabricação que a perpassa. Porque a produção de uma dada obra se acha inevitavelmente ligada a um certo conjunto de práticas e como que irmanada à dimensão do aprendizado, ela acarreta a necessidade de também estarmos instruídos para suas "revelações". Nem mesmo Schelling pode furtar-se a isso. Tanto é assim que afirma: "A única coisa que posso alegar a meu favor é que durante longo período empreendi com seriedade o estudo de obras antigas e modernas da poesia (...) do convívio com aqueles que, além do feliz exercício da arte, também ainda pensaram filosoficamente sobre ela, adquiri uma parcela daquelas visões históricas da arte que creio necessárias para meu fim" (idem, p.26).

Ao atinar para a operosidade que regula o fazer artístico, Schelling não pretende, porém, empreender uma investigação exclusivamente empírica das diversas produções. Se a experiência pessoal acima mencionada achase eivada de ponderações filosóficas, é por que ao esteta interessa retraçar, em cada objeto estético particular, uma totalidade originária, entrevendo, na configuração do belo, um concerto indissolúvel de elementos. E é justamente aqui que a filosofia poderia exercer, por assim dizer, uma espécie de função profilática. Porque é "inteiramente" (idem, p.28) aquilo que é e "não visa de forma alguma o particular como tal" (idem, p.29), a filosofia proveria ao espírito a inteireza de que ele necessita, preservando-o da divisão especializada do saber e resguardando-o da moderna erudição pulverizadora. Afinal, num período em que vigora o aproveitamento atomizado da produção intelectual, em que há, já, uma "filosofia e mesmo uma doutrina-daciência da agricultura, e é de esperar que também se elabore ainda uma filosofia do transporte, e que no fim haja tantas filosofias quantos são em geral os objetos" (idem, p.28), é provável que a própria ponderação filosófica sobre a arte se torne uma condição de impossibilidade. Colocando-nos à distância do homem do presente, dessa "época em que se faz na literatura uma guerra camponesa contra tudo o que há de elevado (...) na qual aquilo que é frívolo, atraente aos sentidos ou valioso de uma maneira torpe são os ídolos aos quais se tributa a maior veneração" (idem, p.24), a filosofia talvez possa reavivar, para o pensamento, as fontes factualmente vitais da arte. Não por acaso, lê-se: "Somente mediante a filosofia podemos ter esperança de alcançar uma verdadeira ciência da arte" (ibidem).

Não se trata, porém, de elevar a reflexão estética acima dos objetos particulares para, a partir do arbitrário abandono de suas características individuais, conceder-lhes, das alturas, a marca de reconhecimento do belo. Para Schelling, não se pode ser esteta de súbito e de uma vez por todas. Àquele que reflete sobre a arte não é dado ascender, em vôo livre e direto, 
rumo à beleza em si, antecipando-se a toda investigação qual uma forma final anterior à matéria que ela mesma forma. A filosofia faz-se necessária à análise, não como se "pudesse conceder o sentido que só um Deus pode conceder, (...) mas porque exprime (...) em Idéias, aquilo que o verdadeiro senso artístico intui no concreto" (ibidem). No fundo, arte e filosofia estariam assentadas em capacidades produtivas iguais, mas desenvolveriam essas potencialidades em direções distintas: aquilo que, na arte, forma-se em direção ao exterior, volta-se, na filosofia, para dentro. A propósito desse fecundo antagonismo, lê-se ainda: "Qualquer um reconhece que opostos se vinculam no conceito de uma filosofia da arte. A arte é o real, objetivo; a filosofia, o ideal, subjetivo" (idem, p.27).

Em virtude disso, seria um tanto frívolo, da parte do esteta, tratar os pares real/ideal e objetivo/subjetivo com vistas à supressão de um dos pólos que neles se tornaram atuante, ou, então, a fim de igualá-los mediante um nivelamento identificador. Não basta desestabilizar a tentativa clássica de definir a obra de arte a partir de sua "verdadeira" estrutura objetiva, tomando por falso em si tudo o que se revelar confuso; cumpre ainda livrar-se do subjetivismo estético, que, visando a uma média empírica do gosto, detémse na análise dos emaranhados psíquicos nos quais se efetua a apropriação pessoal da obra de arte. Do contrário, manter-se-ia apenas às avessas a camisa-de-força imposta pelo dualismo, alimentando uma relação de pura contrariedade sem jamais escapar positivamente à oscilação entre os pólos da dicotomia.

Apostar numa perfeita concordância entre os objetos e os órgãos dos sentidos é endossar a crença de que nossa experiência de mundo e as coisas se recobrem de maneira adequada. Tomar o pensamento por uma atividade silenciosa de enunciação passível de ser considerada verdadeira ou falsa em virtude de descrever corretamente ou não o mundo é reiterar, por outro caminho, a verdade como correspondência, sugerindo que as proposições que emitimos sobre o mundo são válidas antes mesmo de serem balbuciadas por nós. Evitando lançar o pensar contra o sentir - e vice-versa -, Schelling é então levado a situar em outra instância o saber que julga inaugurar. Não somente filosofia nem apenas arte, senão que pura e simplesmente "filosofia da arte": "Nossa ciência deve ser filosofia (...) que deva ser filosofia precisamente em referência à arte, isso é o acidental de nosso conceito. Mas então nem o acidental de um conceito pode de modo algum modificar o essencial dele, nem a filosofia, em particular como filosofia da arte, pode ser algo outro do que é" (idem, p.27-8).

Mas, porque é uma totalidade de ser, o conceito em questão necessita justamente de exibição - e não de uma faculdade apta a unificar, mediante abstração, as propriedades dos objetos, subsumindo, de resto, o particular no universal. A decomposição analítica permite, por certo, refazer os pontos 
que indicam a articulação que atravessa e constitui o objeto a ser analisado, revelando sua estrutura óssea e colocando em destaque os elementos a serem dissecados um por um. Mas, com isso, a impressão estética estaria soterrada em termos de sua demonstração. A confluência simultânea de elementos heteróclitos não constitui, com efeito, a espinha dorsal da objetividade científica, mas o discernimento da obra de arte dela depende. Aqui "cada uma das diferentes figuras é um membro a serviço do todo" (idem, p.29). Se a filosofia da arte é uma imagem da totalidade, então seu conteúdo conceitual deve, por um lado, sujeitar-se à figura a ser contemplada e a imagem precisa, por outro, manter-se permeável ao sentido a ser compreendido. Daí a seguinte pretensão: "Queremos que aquilo que deve ser objeto da exposição artística absoluta seja tão concreto, somente igual a si mesmo, quanto a imagem e, no entanto, tão universal e pleno de sentido, quanto o conceito" (idem, p.74). Depositário generoso da universalidade abstrata do conceito e, ao mesmo tempo, da particularidade concreta da imagem, o modo de exposição de que Schelling irá valer-se ecoa e reedita, à sua maneira, o modo goethiano de intuição, onde "o particular representa o universal, não como sonho e sombra, mas como revelação vital e instantânea do imperscrutável [des Unerforschlichen]" (Goethe, 2000, p.471).

Porque a disposição das artes irá alterar-se conforme a peculiaridade com que o universal nelas se concretiza, Schelling é levado a estabelecer uma ordenação escalonada em diferentes gradações, cujo arranjo se baseia numa dialética entre potências atinentes não apenas ao universo que designa as coisas do espírito, senão que também a inteira natureza: "Aquilo que conhecemos na história ou na arte é essencialmente o mesmo que também existe na natureza: é que a absolutez inteira é conatural a cada um deles, mas essa absolutez se encontra em potencias diferentes na natureza, na história e na arte" (Schelling, 2001, p.28-9). Isso irá assegurar às obras individuais não apenas seu lugar no interior de um sistema estético, mas também numa hipótese de interpretação do desdobramento das próprias forças naturais. É justamente isso que fará da música, como veremos, não apenas uma forma artística ao lado das outras, mas o termo médio graças ao qual se tornará possível - antes mesmo das demais artes - afigurar o "inestético" como algo artisticamente vivo e existente. Como reflexo objetivo e concreto de protótipos ideais, ela tomará para si a condição de mediadora entre espírito e natureza: "A música nada mais é que o ritmo prototípico da própria natureza e do próprio universo, que por intermédio dessa arte irrompe no mundo afigurado" (idem, p.31).

Porque considera a música como a mais física e material das artes, Schelling também é levado a concebê-la, dialeticamente, com a mais espiritual e refinada. Ou, para trazer à baila o comentário perspicaz de Luigi Pareyson, a arte dos sons se acha "enterrada na mais elementar e bruta natu- 
ralidade, e, por outro lado, está aberta à pureza mais elevada das idéias" (Pareyson, 2000, p.42). Sendo a primeira e mais básica forma artística, a música representa como que o ponto de partida do movimento pelo qual a completa indiferença do universal e particular se converte num efetivo objeto artístico. A fim de acompanhar alguns passos argumentativos que perfazem esse processo cumpre indicar, antes, a maneira pela qual o discurso filosófico sobre a música nasce e cresce dentro do próprio criticismo. Pois, em que pese o distanciamento tomado pelo autor da Filosofia da arte, é ainda a partir da filosofia crítica que a estética musical irá, malgrado o próprio criticismo, levar a água ao seu moinho, insinuando-se com seus próprios e legítimos interesses.

\section{Em Kant, o ensejo}

Que não exista, no pensamento de Kant, uma teoria da arte acabada, bem como um discurso unívoco sobre o âmbito que designa a atividade musical, eis algo que nenhum intérprete estaria disposto a negar. Embora atento a questões tais como a da relação entre o gênio e as belas artes, bem como a dos próprios limites da sensibilidade, ele não se pretende crítico de arte e tampouco espera analisar a operosidade que comanda o fazer artístico propriamente dito. Ao contrário, em sua obra, a arte vem à baila vinculada à questão acerca da atividade do juízo, sendo que é justamente isso que irá constituir a pedra de toque do veredicto contido na apreciação kantiana da música: esta, no entender do filósofo, não se deixa apreender, sem problemas, sob a forma de um juízo estético. Que este último apresenta inúmeras peculiaridades, eis algo que se nota ao longo dos diversos momentos em que se procura determiná-lo. À diferença dos juízos-de-conhecimento, que se fiam na aplicação de conceitos objetivos sobre as intuições, é a um sentimento que o juízo-de-gosto deve sua condição de possibilidade. Trata-se, em realidade, de uma curiosa espécie de satisfação, cuja exposição conceitual tem lugar, de modo lapidar, no $§ 2$ da "Analítica do belo":

Interesse é denominado a satisfação que vinculamos com a representação da existência de um objeto (...) Mas, se a questão é se algo é belo, não se quer saber se, para nós ou para quem quer que seja, importa algo a existência da coisa, ou sequer se pode importar; mas sim como a julgamos na mera consideração (intuição ou reflexão) (...) a mera representação do objeto, em mim, é acompanhada de satisfação, por mais indiferente que eu possa ser quanto à existência do objeto dessa representação (...) É preciso não ter a mínima preocupação pela existência da coisa e, a esse respeito, ser inteiramente indiferente, para fazer papel de juiz em assuntos de gosto. (Kant, 1974, p.210) 
Reflexiva, a faculdade estética de julgar não prevê um universal que lhe servisse de suporte. Subjetivo, seu fundamento-de-determinação não pode ser um princípio conceitualmente determinado. Pergunta-se, porém: como pode uma satisfação arvorar-se em validez universal? Kant acredita tornar isso plausível mediante a admissão de que, na satisfação desinteressada à base do juízo, encontra-se em ação uma atividade intelectual que, em seu conjunto, não pode mais subsistir nem no âmbito prático da razão nem em sua instância teórica, enquadrando-se, pois, nos parâmetros de uma pródiga complementaridade entre as faculdades. Guardando autonomia em relação às demais operações - apesar de com elas concordar -, o juízo-de-gosto dará ocasião a uma comunhão vivificante entre a imaginação e o entendimento, sendo que é o tomar consciência desse acordo que, segundo Kant, pode dar-nos a solução à suposta universalidade contida no juízo-de-gosto: "A comunicabilidade universal subjetiva do modo-de-representação em um juízo-de-gosto (...) não pode ser outra coisa que o estado-da-mente no livre jogo da imaginação e do entendimento (na medida em que concordam entre si, como é requerido para um conhecimento em geral)" (idem, p.220).

Curiosamente, a música irá como que obstaculizar tal realização criativa por parte do sujeito. E, a menos que se encontre uma alternativa, a estética musical terá seu passo cortado antes mesmo de adentrar no horizonte hermenêutico da filosofia crítica. Assim é que, fazendo coro com a estética filosófica setecentista, o autor da Crítica do juízo tratará então de empreender uma divisão das diferentes artes conforme seus respectivos gêneros. Ao fazê-lo, no entanto, ele não deixa de explicitar, ao mesmo tempo, o expediente metodológico de que se serviu. Trata-se, de acordo com suas palavras, de uma "analogia da arte com o modo de expressão de que os homens se servem no falar" (idem, p.256). E também revela, numa concisa, mas relevante observação, que tal esboço de divisão está longe de ser algo conclusivo, permanecendo à parte, aliás, do próprio sistema da filosofia transcendental. Ad hoc, ele é tão-só uma dentre as muitas tentativas que ainda "se podem e devem fazer". Feita a ressalva e dando cumprimento ao plano, Kant irá distinguir três traços principais no interior da linguagem humana: a palavra (articulação), o gesto (movimento) e o som (modulação). Hauridos dessa divisão tripartite, os correlatos artísticos de tais modos de expressão são, logo após, agrupados em torno dos seguintes núcleos: as artes elocutivas (eloqüência e arte poética), as artes figurativas (plástica [escultura e arquitetura] e pintura) e a assim chamada "arte do belo jogo das sensações (que são engendradas do exterior)" (idem, p.259). Não se deterá aí, porém, a classificação. Sobre o belo jogo das sensações recairá ainda uma última subdivisão - justamente a que nos interessa -, que vem à luz sob a forma de uma curiosa disjunção entre o jogo artístico atinente à audição e à visão, ou, como se lê, entre "música e arte das cores". 
Atrelada a uma significação notadamente ampla da sensibilidade artística, a caracterização da arte dos sons e das cores enquanto "jogo das sensações" cederá terreno, contudo, a uma insidiosa suspeita. Empreende-se a pergunta pela possibilidade mesma de a música, bem como a arte das cores, ter algo a ver com as belas artes, ou, melhor dizendo, com obras cuja beleza é experimentada sob a égide do livre jogo das faculdades e sob o influxo de uma satisfação desinteressada. Irremediavelmente submetidas à força do interesse e das inclinações, as sensações parecem estar como que destinadas, de antemão, a motivar sentimentos agradáveis ou desagradáveis - e, portanto, nos quais apenas juízos de validade individual se deixariam fundamentar. Sinuoso, o caminho entrevisto por Kant para tentar solucionar a questão abriga obstáculos. Afinal, como ele dirá: "Não se pode dizer com certeza: se uma cor ou um tom (som) são meramente sensações agradáveis, ou em si já um belo jogo de sensações e, como tal, trazem consigo uma satisfação face à forma no julgamento estético" (idem, 260). À primeira vista incontornável, essa dificuldade irá, não por acaso, impelir a análise kantiana a um outra conseqüência. Bifronte, a arte dos sons implicará a adoção de um duplo ponto de vista sobre o jogo operado pelas próprias sensações.

Concebidas somente enquanto efeitos sobre o sistema receptivo do ouvinte, as sensações sonoras adquirem, aqui, um sentido ligado ao âmbito indelineável dos sentimentos de agradabilidade e descontentamento. Mas, se por aí não fazemos senão nos abandonarmos aos "estremecimentos sobre a parte elástica de nosso corpo", talvez nos fosse facultada uma saída por meio da adoção de uma outra postura em face das mesmas sensações. Tomadas enquanto intuições na forma do tempo e espaço, e, desse modo, enquanto portadoras de uma estrutura determinada, as impressões do puro som em movimento talvez pudessem fornecer - a título de vibrações do ar proporcionalmente apreendidas - pontos de referência propícios à realização de um efetivo jogo artístico das sensações. Implicando atinar com as relações espaciotemporais estabelecidas nas progressões sonoras - ou, como nos diz Kant, com "a divisão do tempo" (ibidem) -, tal disposição requer, ao menos, uma certa atividade cognitiva por parte das faculdades, tornando exeqüível, nesse trilho, uma apreciação estética mediante a faculdade do juízo. Sobre as diferentes tensões da escala de cores e sons, surgem, agora, outras considerações: "poderíamos ver-nos obrigados a considerar as sensações de ambos [das cores e dos sons] não como mera impressão sensível, mas como o efeito de um julgamento da forma no jogo de muitas sensações". Contudo, e apesar da dupla referência às sensações, o autor da Crítica do juízo parece não mudar substancialmente de atitude diante da arte dos sons. Assim é que, comprometido com o plano original, ele passa a considerar uma hierarquia das belas artes conforme um critério "extra-artístico", tomando como fundamento "a ampliação das faculdades que no Juízo 
têm de reunir-se para o conhecimento" (idem, p.263). Devido à sua atávica falta de conteúdos conceitualmente descritíveis, a música acaba por ocupar o lugar menos relevante em tal ordenação. ${ }^{3}$

Para Schelling, no entanto, o ensejo proporcionado pela apreciação kantiana não se encontra exatamente lá onde ela pretende discorrer acerca da arte dos sons, mas no fato de ela conceber uma operação reflexiva de cunho cognitivo - mediada, portanto, não apenas pelo sentimento - como sendo constitutiva da experiência estética. E, justamente porque não visa à construção de uma "teoria", o autor da Filosofia da arte não descobrirá nenhuma impotência no fato de a música ser incapaz de suscitar um prazer puro, isto é, livre de qualquer motivação interessada; da ambigüidade que cruza e constitui os sons ele conta retirar, ao contrário, uma vantagem. Como toda produção artística, a criação musical oferece obras nas quais as partes só têm sentido dentro de um todo e este, por seu turno, tem seu fim em si mesmo, ostentando uma dinâmica que lhe é intrínseca e que se coloca, por conta própria, à decifração.

Pouco importa que as leis que regem o objeto em questão não encontrem amparo num fundo semântico plenamente codificado. Afinal, a intuição em pauta não supõe um correspondente perfeitamente adequado. Pouco importa que não haja, no caso, uma semelhança de conteúdo com algum conceito ou signo determinado. Afinal, a crua teia de relações sonoras percebida pelo ouvinte formaria, anteriormente às imagens acústicas usadas para formação do signo lingüístico, um campo liberto da tirania do significado. Isso fornece alguns indícios daquilo que aqui está efetivamente em jogo: evitar que se reduza a exposição a uma função representativa de caráter alegórico, que se refere sempre a outra coisa que não a ela mesma. Inseparável de seu próprio conteúdo, a forma do signo musical cuidaria, já, de sua significação, sem ter de recobrir "coisas" por meio de designações conceituais, arrastando consigo substâncias e causas exteriores. A exigência que aqui se satisfaz é, em última análise, a mesma que Schelling encontrará na mitologia. Também em música "a significação é ao mesmo tempo o próprio ser, é passada para o objeto, é um com ele" (Schelling, 2001, p.73).

3 A música também é imputada, nesse mesmo contexto, uma determinada ausência de "civilidade", que vem à tona sob a forma do seguinte comentário: "Além disso, prende-se à música uma certa falta de urbanidade, pois ela, principalmente conforme a índole de seus instrumentos, amplia sua influência além do que se lhe pede (à vizinhança) (...) portanto faz dano à liberdade de outros, fora da sociedade musical; o que as artes que falam aos olhos não fazem, na medida em que basta desviar os olhos, se não se quer aceitar sua impressão" (Kant, 1974, p.264). 


\section{No ritmo, a música}

Disposto a explorar em profundidade os recônditos do sensível e decidido a criar condições para que a sensibilidade artística se reconcilie com o outro de si, Schelling não procurará vincular apreciação estética apenas a uma atividade do sujeito. Este, a seu ver, não pode fundamentar-se nem na unidade primária da consciência pensante nem em alguma certeza imediata que pudesse ser vista como semente de uma entidade subjetiva. Não por que considera a subjetividade apenas um efeito formal da síntese levada a cabo pelo pensar, mas por entender que a própria natureza fornece o estofo do pensamento. Longe de figurar como um mero obstáculo à atividade de um eu que desconhece limites, a natureza formaria, não ao lado, mas junto com a consciência, uma unidade infinita e indiferente. A distinção meramente relativa entre ambas estaria em que, na natureza, a atividade produtiva responsável por seu desabrochar permanece inconsciente. É nesse sentido que ganha lastro e plausibilidade a dupla orientação descrita na Introdução ao projeto de um sistema da filosofia da natureza: "A inteligência é produtiva de dois modos, ou cega e inconsciente ou livre e com consciência; inconscientemente produtiva na intuição do mundo, com consciência na criação de um mundo ideal" (cf.Schelling, 2004).

Partidário do naturalismo organicista, Schelling recusa-se a conceber a natureza como um não-eu ou uma concreção mecânica regida por leis estranhas aos seus produtos. Puro agir, ela seria, no fundo, uma auto-atividade cumpridora de um tipo insaciável de "enteléquia", que nunca se detém frente às potencialidades que se lhe opõem, expressando, assim, um impulso inexaurível à dispersão e um desejo desenfreado de consumar-se mais e mais. O processo que caracteriza a esfera da imanência se efetuaria, sob esse prisma, a partir de um sistema de mútuas oposições que, depois de superadas, produziriam novas contradições, organizando-se progressivamente até chegar, na obra de arte, à consciência de si. Eficiente, a causa que aqui se torna atuante participaria na produção de seus efeitos, de sorte que o sujeito, mero epifenômeno de forças originalmente inconscientes, não poderia deixar de manifestar o que nele há de orgânico e natural. Porque é uma instância em que a subjetividade se acha livre da abstração, a arte torna-se o lugar no qual a inteligência produtiva pode exprimir livremente suas potencialidades. Porque aproxima a música mais diretamente da natureza, Schelling fará da arte dos sons a mediadora entre espírito e matéria.

É bem verdade que, com isso, o autor da Filosofia da arte revela-se fatalmente um filho de seu tempo, enredado, por um lado, em algumas dificuldades apontadas pelo criticismo e influenciado, por outro, pela idéia notadamente romântica de que se pode obter, por meio da arte, um acesso à estrutura ontológica da existência. A esse propósito, aliás, comenta Berbeli 
Wanning: "Num certo sentido, ele [Schelling] permanece comprometido com sua época: a convicção romântica de que, na multiplicidade das aparências, esconde-se sempre uma origem comum, transformando a simples escala valorativa das formas artísticas, que até então constituía o fundamento de todas as respectivas hierarquizações, numa matriz dialética" (Wanning, 2003, p.86). Mas é certo ainda que a relação de Schelling com a tradição é, em boa medida, caracterizada pela ambigüidade. À diferença dos outros autores, ele pretende apresentar a música como uma das formas básicas das assim chamadas artes plásticas. Para tanto, ele trata de dispor a arte numa série real e numa série ideal, a depender se nela se manifesta o aspecto físico ou o lado espiritual: "A cada uma dessas formas, se estão compreendidas na unidade real ou na ideal, corresponde uma forma particular da arte" (Schelling, 2001, p.32). Sob a série real, recairão então as artes plásticas, representadas, numa tríade aparentemente desconfortável, pela música, pintura e escultura, ao passo que, à série ideal, corresponderão as ditas artes literárias, ou, mais especificamente, as formas lírica, épica e dramática da poesia.

Extravagante, a escolha reflete, porém, uma consciente opção metodológica. O autor da Filosofia da arte poderia ter irmanado a música às suas potencialidades paralelas no interior da série ideal, como, por exemplo, ao lado da poesia lírica. Com isso, teria feito coro com aqueles que sempre tomaram a lírica pela mais "musical" dentre todas as formas da poesia. Mas, lançando mão de um outro olhar, ele se volta explicitamente contra as apreciações que reduzem a música a uma mera arte dos sentimentos e "do jogo das sensações". Em vez de reduzi-la a uma intuição primeira ou validar o triunfo da subjetividade, ele espera, ao contrário, expor a arte dos sons em sua "materialidade". Para fazer jus à insígnia de "músico", o poeta lírico agora teria, por assim dizer, que se desfazer dos condicionamentos subjetivos de sua vontade individual e abismar-se na matéria, identificando-se, aí então, com a efetividade que o cerca. Cumpre, porém, indagar: que aspecto material é esse de que fala Schelling?

O texto schellingiano refere-se à materialidade física da sonoridade (Klang). Esta, por seu turno, corresponderia à completa indiferença entre sujeito e objeto, finito e infinito, condensando-se, pois, na expressão da derradeira identidade dos contrários: "Na formação-em-um do infinito no finito, a indiferença, como indiferença, só pode aparecer como sonoridade" (idem, p.147). Valendo-se de considerações consoantes à sua filosofia da natureza, Schelling procura ilustrar essa idéia por meio de um paralelismo entre a implantação do infinito no finito no processo de construção da matéria e a transmissão do som pelos corpos no âmbito da sonoridade. O argumento considera que, no primeiro caso, a implantação da matéria exprimese, desde logo, pela primeira dimensão física, ou, como quer o filósofo, pelo 
magnetismo, mas ressalta, a seguir, que tal dimensão não pode, aqui, introduzir-se puramente como tal, senão que simultanemente com a segunda (eletricidade) e a terceira (processo químico), em virtude da síntese por elas operada. Noutros termos, a formação-em-um não pode, na matéria, ser exposta puramente como tal. A transmissão, aqui, não prescinde de um corpo que a transmita: "O próprio ato da implantação é expresso no corpo como magnetismo, (...) mas o magnetismo, assim como a primeira dimensão, é de novo vinculado ao corpo, portanto não é formação-em-um mesma, puramente como tal, mas diferença" (idem, p.148). Porque também se insere na dimensão do tempo, a sonoridade pode dar-se ao luxo de exprimir a indiferença como tal, fazendo as vezes de um magnetismo separado da corporeidade: "Pois esta [a sonoridade] é, de um lado, viva - por si -, de outro, uma mera dimensão no tempo, mas não no espaço".

Interface entre o orgânico e inorgânico, a sonoridade condensa e reflete o sistema dialético de oposições. Sintomático disso seria o próprio órgão da audição. Nele, a natureza inorgânica, na figura do magnetismo, integrase ao seu oposto. Como dirá Schelling a esse propósito: “Também o órgão da audição consiste exteriormente em corpos rígidos e sonoros, só que a essa unidade está ligada a oposta, a do recolhimento da diferença do som na indiferença" (idem, p.149). O ouvido, nesse sentido, seria o magnetismo desenvolvido até a perfeição orgânica, integrado a esta última por meio das duas unidades que coexistem e dormitam sob a audição. Na atividade auditiva, a natureza torna-se pela primeira vez autoconsciente, na medida em que se coloca à escuta de si mesma. Ouvido que se ouve, "ela se torna = ouvido".

É, no entanto, no mesmo instante que uma coisa se integra a outra. Não há, primeiro, magnetismo e, depois, corpo sonoro "atualizado". Dizer que "corpo algum ressoa a não ser que ao mesmo tempo transmita som" (idem, p.148), é dizer, mas sem perder de vista esse ao mesmo tempo, que a condição do som é que "o corpo seja posto fora da indiferença". Concomitantemente, nenhum som distinto poderia determinar-se sem ter feito parte, como possibilidade, de um amálgama vazio de diferenciações. É certo que, na sonoridade, não ouvimos só o som simples, mas "uma porção porção de sons como que nela envolvidos", e todos concorrendo para um concatenado jogo de tensão e afrouxamento; mas é certo ainda que, como potencialidade, a sonoridade indistinta como que antecede essa escuta. O desafio consiste em afirmar essa relação virtual de anterioridade sem ceder à tentação de enquadrá-la nas hostes da metafísica do ato e da potência - que aqui decerto desvirtua o raciocínio. A sonoridade remete a sons determinados, mas sua significação é o objeto sonoro em geral. Dizer isso é dizer que ela é a precondição para que exista ocorrência sonora. Como? Então o som é possível porque a sononoridade é possível? A é igual a A? Sim, mas desde que se enten- 
da essa identidade, não partir do princípio de não-contradição, senão que no sentido transitivo, como convergência de ser e significação.

Essa maneira de pensar possibilitará a Schelling afirmar, daí em diante, que os elementos musicais que se contradizem entre si não oferecem, em sua presença efetiva, outra contrariedade a não ser a de participarem de modos distintos da matéria sonora informe e não organizada: "Cada unidade em sua absolutez, compreende de novo todas as outras, portanto também a música compreende" (idem, p.150). À vivência dessa união entre opostos, pensada como sonoridade, somos conduzidos mesmo quando o ouvido treinado se prende ao rigoroso controle dos detalhes, quer diferenciando notas estranhas à função dos acordes, quer localizando consonâncias perfeitas no fundo, "coexistentes" à sonoridade: "O ouvido exercitado até mesmo os distingue e, além do uníssono ou do tom fundmental, ouve também sua oitava, a oitava da quinta etc. (...) A multiplicidade, que na coerência como tal está vinculada à unidade, torna-se, portanto, na sonoridade, uma multiplicidade viva" (idem, p.149). Porque essa multiplicidade sonora se afirma mediante a sucessão - à diferença do ruído, mistura sonora interrompida que, incapaz de criar e manter pontos contínuos de sustentação, "não deixa reconhecer nitidamente a unidade na multiplicidade" - Schelling permite-se explorar a dimensão em que a sonoridade suspende, por assim dizer, seu caráter "material", fundindo-se com a temporalidade e permitindo, assim, a multiplicidade de sons fluir dentro na unidade da sonoridade.

Como forma abstraída de todo o real, o tempo é consciência-de-si, ou, mais precisamente, "formação-em-um da unidade da consciência na multiplicidade" (idem, p.150). Mas, como música, ele adquire uma acepção ligada ao sentido auditivo, vindo à baila como uma "enumeração-de-si real da alma" e, como tal, uma enumeração inconsciente - que "de novo se esquece de si mesma". Esse lado a lado de consciência e inconsciência é, pois, conservado na música por aquilo que ela tem de temporal, sendo que é por aí que se pode começar a compreender seu papel ao mesmo tempo ambíguo e poderoso dentro da série das artes plásticas - considerando, é claro, a pintura e a plástica como formas espaciais. Se destas últimas a música se afasta devido à sua forma, compreende-as, porém, do ponto de vista qualitativo. Porque essa prerrogativa se deve à sucessão, é precisamente no ritmo que, segundo Schelling, encontramos a chave para compreensão de sua explicação. Não por acaso, ele trata de reeditar, na música, as premissas contidas em sua divisão geral das formas artísticas. Assim como a música constitui a primeira potência da série real, nela o ritmo também irá vigorar como potência primeira, seguida pela modulação, a título de elemento pictórico, e pela melodia, que aqui corresponderá à plástica. Assumindo-se como aquilo que há de musical na própria música, o ritmo realiza, no interior da arte dos sons, aquilo que esta última possibilita, isto é, a formação-em-um da 
unidade na multiplicidade. Por isso, "ele [o ritmo] é a música na música e, portanto, conforme a natureza dessa arte, o dominante nela" (idem, p.152).

Divisão periódica do homogêneo, o ritmo vincula o uniforme à diversidade. Subjugando valores de durações diversas a uma regularidade, ele imprime ordenação a elementos que, isoladamente, seriam indiferentes entre si. Que esse sujeitar e ordenar exerce profunda influência sobre as disposições afetivas, eis algo que não escapa a Schelling. Tão logo sons e batidas terminem por retornar juntos sob determinados períodos, "somos irresistivelmente levados a prestar atenção neles". Pulsante, o próprio corpo humano apresentar-se-ia, no limite, como uma concreção passivamente excitável pelas relações rítmicas, movida e afetada, por assim dizer, pelo pathos das divisões periódicas. Contagiante e multiplicadora, a força do ritmo exercese sobre as mais básicas funções reguladoras, impondo-se, inclusive, sobre a freqüência mesma das atividades mecânicas. Que disso o próprio trabalhador retira uma utilidade e um certo refrigério, eis algo que tampouco escapa ao filósofo: "Impelido pela natureza, o homem procura, por meio do ritmo, pôr multiplicidade ou diversidade em todas aquelas ocupações que, em si, são uma pura identidade (...) É com isso que a maioria dos trabalhadores mecânicos torna mais leve o próprio trabalho" (idem, p.151).

Mas, para além daquilo que o ritmo tem de excitante e atraente, o autor da Filosofia da arte espera descerrar uma dimensão mais recuada e importante. É aqui que intervém, estrategicamente, a noção de cadência. Com ela, trata-se de indicar uma "espécie mais alta de unidade na diversidade" (idem, p.152), onde o idêntico pode tornar-se diferente de diferentes modos. Já não se trata apenas de transformar uma sucessão meramente uniforme, já de si insignificante, numa sucessão significativa, aprazível e excitante. É preciso ainda indicar que a sucessão como tal - isto é, como série de membros que se tangem arbitrariamente - tem o caráter da contigência e que a transformação da sucessão em "necessidade = ritmo" implica um redimensionamento por meio do qual "o todo já não é submetido ao tempo, mas o tem em si mesmo". Com isso, atingimos o duplo aspecto que faz do ritmo algo decisório para explicação schellingiana: por meio da temporalidade que lhe é imanente, o ritmo acha-se ligado à consciência de si; por meio da simples regularidade, ele se liga às forças elementares do corpo e da natureza. Falta apenas indicar o modo pelo qual essa potência domina, dialeticamente, as outras duas que lhe seguem, o mesmo é dizer, a modulação e a melodia.

Schelling não utiliza o termo modulação enquanto uma categoria intrínseca ao sistema harmônico tradicional. Se a ele não importa erigir uma "teoria" da arte, tampouco teria cabimento, a essa altura, abandonar a construção filosófica da música em prol da significação técnica do termo. Afinal, como ele mesmo irá dizer: "Conduzir canto e harmonia, mediante as chamadas modulações e resoluções, através de vários tons, para enfim voltar 
de novo ao primeiro tom fundamental, é um modo artístico que já pertence inteiramente à arte moderna" (idem, p.153). Como o valor expressivo de um determinado acorde depende da relação com os demais agrupamentos sonoros da estrutura harmônica, adquirindo diferentes matizes em virtude de se aproximar ou não de um centro tonal fundamental - dele se afastando, por exemplo, como subdominante, ou, então, dele se aproximando como dominante -, o autor da Filosofia da arte verá aí a possibilidade de atribuir à modulação uma difícil tarefa: expor a identidade a partir da própria diferença qualitativa entre os tons e acordes. "Nesse aspecto," diz ele "modulação é então a arte de manter, na diferença qualitativa, a identidade do tom que é dominante no todo de uma obra musical". Mas, como vimos, uma efetiva diferença qualitativa é, por definição, impensável na filosofia da arte. E agora é a própria música que parece estar surda, por assim dizer, à sonoridade indiferenciável sobre a qual está assentada. E não só. Ao referir a percepção rítmica à unidade quantitativa e o discernimento da estrutura harmônica à unidade qualitativa, a apreciação schellingiana ainda corre o risco de deixar entrar, pelas portas do fundo, a divisão entre uma arte a ser percebida pelo ouvido e uma outra a ser reconstruída pelo entendimento.

É justamente nesse horizonte de elevada tensão que entra em cena, então, a terceira potência da música, a saber, a melodia. Com ela, Schelling espera indicar a soma de ritmo e modulação: "A terceira unidade, na qual as duas primeiras [ritmo e modulação] estão equiparadas, é a melodia" (ibidem). Se pela dimensão temporal a música acha-se determinada para consciencia-de-si e pela modulação para o juízo, pela melodia, dirá o filósofo, ela encontra-se determinada "para a intuição e imaginação" (idem, p.154). Aquilo que o ouvido, por si, não consegue discernir e aquilo que juízo não consegue escutar, pode, no entanto, ser concedido à imaginação por meio da melodia. Se a identidade quantitativa à base divisões rítmicas e a identidade qualitativa subjacente às distâncias intervalares entre os sons contraria, pois, na música, o pensamento da identidade dos opostos, este último é recuperado pela impressão "plástica" atinente à imaginação melódica. Com vistas à construção da filosofia da música, talvez pudéssemos dizer que o ritmo é aquela exposição na qual o universal significa o particular, a modulação aquela em que o particular significa o universal e a melodia, por seu turno, a síntese das duas, onde nem o universal significa o particular nem o particular o universal, mas onde ambos são um.

Essa combinatória precisa, no entando, ser matizada. Tal como foi por nós arrolada, poderia enrredar-nos num raciocínio triádico que ela não comporta. Afinal, a posição da melodia como terceira potência tende a caracterizá-la, à primeira vista, como um retorno à tese (ritmo) a partir da negação da antítese (modulação), situando-a, por esse movimento, como a mais alta unidade. Sabemos, contudo, que cabe ao ritmo desempenhar essa função: 
"Ritmo, pensado na absolutez, é toda música (...) então ele compreende imediatamente em si a outra unidade e é, por si mesmo, melodia, ou seja, o todo". Mas, para não confinar sua reflexão nos quadros de uma contradição irresoluta, Schelling trata então de situar ambas unidades de modo absoluto: "o ritmo, na significação indicada (isto é, compreendendo a unidade oposta), e a melodia são eles próprios novamente o mesmo". O todo da música é música rítmica, pois nesta as unidades não são diferentes nem segundo a modulação nem segundo a melodia. E, fazendo um balanço da combinatória acima indicada a partir dessa nova unidade - no seio da qual "a melodia nada mais é que o ritmo integrado" (idem, p.156) - o melhor seria dizer que a música rítmica expõe o infinito no finito precisamente lá onde "este (o finito) vale algo por si mesmo". Por isso, adotar um critério mais rítmico para estruturação musical equivaleria, no limite, a assumir uma perspectiva oposta ao moderno sistema de encadeamento de acordes, onde "a finitude ou diferença aparece somente como uma alegoria do infinito ou da unidade".

Não por acaso, Schelling irá eleger a música dos antigos como o ideal retrospectivo mais condizente com a entranhada vocação rítmica dos sons. É bem verdade que, fiando-se no Dicionário de música de Jean-Jacques Rousseau - "ainda a obra mais bem pensada sobre essa arte" (idem, p.154) -, ele nos lembra que sabemos muito pouco sobre a música antiga. Mas, ainda assim, parece convencer-se de que, não só "os gregos foram grandes em todas as artes" (idem, p.155), como também o princípio plástico e realista teria dominado a música dos antigos - e isso "unicamente porque tudo estava subordinado ao ritmo". O essencial dessa música, da qual o único vestígio "se encontra, embora altamente dissimulado, no canto coral", estaria contido na força e no andamento da melodia ritmada. E, ainda que esta tenha perdido "toda energia", Schelling ainda acredita vislumbrar, pelas lentes Rousseau, a prestigiosa coloração de sua paleta sonora: "A despeito de todas essas falhas, no canto coral, conservado em seu caráter original pelos padres da Igreja romana, Rousseau também encontra algo de grande valor que restou do canto antigo e de seus diferentes modos."

É o que basta para situar Schelling no interior da querela entre os antigos e modernos, que se engalfinham em nome da melodia e harmonia. ${ }^{4}$ Ao

4 Tendo em vista a ampla tradição na qual esse embate se insere, seria o caso de volver, aqui, à sua procedência histórica. Como se sabe, não tardou para que as relações harmônicas despertassem o interesse de filósofos e homens de ciência desejosos de exprimir certas ocorrências sonoras em termos dos mais inconcussos princípios teóricos. Não por acaso, foi a partir da promoção dos intervalos sonoros a efeitos sensíveis distintamente identificáveis que Pitágoras, buscando suportes a seu pensamento, "descobriu o cânon musical do monocórdio" (cf. Laertios, 1998, Livro 8, p.375). E tampouco faltou quem sugerisse que as qualidades sonoras percebidas sob tais intervalos seriam decorrentes de uma causalidade mecânica irrefutável. Galileu decerto adquire, a esse respeito, lugar de destaque: "Digo que a razão primeira e imediata da qual dependem as relações dos intervalos musicais não é nem a longitude das cordas nem sua tensão e tampouco sua espes- 
enaltecer o idioma sonoro usado no canto coral, o autor da Filosofia da arte opta pelo registro melódico-linear em detrimento da concatenação harmônica, situando-se, com isso, a contracorrente da modernidade artística e da música da qual ele se sabe fatalmente contemporâneo. Denso e movimentado, o amalgamento sonoro que caracteriza a harmonia do século XIX não só deixou para trás os antigos princípios de estruturação musical como também deu início, por meio da harmonia cromática e de um tratamento mais livre da dissonância, ao processo que termina por dissolver os próprios cânones da tonalidade. Mais próximo da simplicidade dos antigos conjuntos vocais do que do acento pictural da harmonia moderna, Schelling não poderia estar mais distante das diretrizes estéticas de seu século. Ironicamente, o dodecafonismo consoante à primeira metade do século XX irá pautar-se por uma perfilação fundamentalmente linear das vozes, resgatando, a seu modo, meios tradicionais de estruturação contrapontística - ecoando, nesse sentido, as características do canto coral. Imputar a Schelling, porém, a marca de um conservadorismo retrógrado é ignorar o teor "universal" de sua ponderação. Se isso acarreta algumas dificuldades de interpre-

sura, mas a proporção existente entre a freqüência de vibrações e, portanto, das ondas que, propagando-se no ar, terminam por impactar o tímpano da orelha fazendo-o vibrar com o mesmo intervalo de tempo" (Galilei, 1970, p.85). Antológica é ainda a tentativa de erigir regras harmônicas incontestes a serem arrancadas, à cartesiana, de certezas objetivamente transparentes ao espírito. Foi desse modo que Rameau, operando com o princípio de causalidade segundo o qual a causa deve conter tanto ou mais realidade objetiva do que o efeito, tratou de definir os intervalos musicais: "em cada som, todos os agudos estão contidos no grave, mas não reciprocamente"(Rameau, 1722, Livro I, Cap.3, p.3). Se tais empreendimentos acreditavam acicatar, como precondição de sua compreensibilidade, uma harmonia estruturada a partir de princípios indubitáveis, houve igualmente quem buscasse legitimar a arte dos sons não por meio da expressão racional de certos princípios clarividentes, mas, antes, pelos efeitos sentimentais comumente atribuídos à melodia e pela proeminência da própria comunicação afetiva no âmbito musical. Pois, se para fazer jus à interpretação rameauniana impõe-se explicar a melodia tão-só a partir da teoria harmônica - haja vista que caberia a esta última, segundo Rameau, "determinar, de antemão, uma rota a cada uma das vozes" (idem, Livro II, Cap.19, p.138) -, com Rousseau as tentativas de explicação assumem um rumo de todo diferente, importando, antes do mais, situar as vozes no contexto da expressão melódico-humana. "A melodia" - lê-se, nesse sentido - "ao imitar as inflexões da voz, exprime os lamentos, os clamores de dor ou alegria” (Rousseau, 1970, p.159). Tendo em vista a comparação da linha melódica com atributos "naturais" do canto - este sim, a seu ver, eivado de "inflexões vivas" (cf. Rousseau, 1995, p.884) -, tal pensador esperava então revelar o caráter propriamente convencionalista da harmonia: "É bem difícil deixar de supor que toda nossa harmonia não passe de uma invenção gótica e bárbara" (idem., p.884). Opondo-se à aridez e artificiosidade em coisas do espírito, ele julgou ainda ser possível pressupor elementos musicais aos quais as próprias paixões estariam, em princípio, ligadas por vínculo afetivo: "Os sons, na melodia, não atuam sobre nós somente enquanto sons, mas como signos de nossas afecções, de nossos sentimentos" (idem., p.163). Acautelando-se contra o uso do som pelo som, a ele lhe pareceu particularmente importante assegurar o primado da expressividade no terreno musical: "O músico que espera promover o ruído pelo ruído se ilude (...), pois, não basta que ele imite, é preciso que ele comova [il faut qu'il touche]" (Rousseau, 1970, p.161). 
tação - já que a arte só adquire significado quando inserida numa explicação de conjunto amplamente articulada -, cabe afirmar que é precisamente esse aspecto que fará da música não apenas um tópico entre outros, mas a coluna vertebral de uma fecunda filosofia: a filosofia da música.

\section{Agradecemos ao CNPq.}

BARROS, Fernando de Moraes. Schelling and the constitution of music asthetics. Trans/Form/Ação, (São Paulo), v.30(2), 2007, p.93-114.

- ABSTRACT: In line with Schelling's theory of art, this article aims at investigating the very process of constitution of music asthetics. To accomplish this task, it intends to show the way the German philosopher transforms the foundations of the so called sistematic aesthetics in order to characterize music as an original object of knowledge.

- KEYWORDS: Schelling; Kant; art; music; rhythm; modulation; melody.

\section{Referências bibliográficas}

BOENKE, Michaela. Transformation des Realitätsbegriff - Untersuchungen zur frühen Philosophie Schellings im Ausgang von Kant. Stuttgart: FrommannHolzboog-Verlag, 1990.

EGGEBRECHT, Hans Heinrich. Die Musik und das Schöne. Munique: Piper-Verlag, 1997.

FRICKE, Christel. "Kant". In: Musik in der deutschen Philosophie. Stuttgart: MetzlerVerlag, 2003, p.21-38.

GALILEI, Galileo. Discours et démonstrations mathématiques concernant deux sciences nouvelles. Première Journée. Trad. de Clavelin. Paris: Colin, 1970.

KANT, Immanuel. Kritik der reinen Vernunft. Hrg. Wilhelm Weischedel. Frankfurt am Main, Suhrkamp, 1974.

Crítica do Juízo. In: "Os Pensadores". Tradução de Rubens Rodrigues Torres Filho. São Paulo: Abril Cultural, 1974.

LAERTIOS, Diogenes. Leben und Lehre der Philosophen. Trad. por Fritz Jürss. Stuttgart: Reclam, 1998.

PAREYSON, Luigi. "L'esthétique musicale de Schelling". In: Philosophie. Paris: Les editions de minuit, 2000, p.20-45.

RAMEAU, J.-Ph. Traité de l'harmonie réduite à sés príncipes naturels. Paris: Ballard, 1722

ROUSSEAU, J.-J. Essai sur l'origine des langues: ou il est parlé de la melodie et de l'imitation musicale. Paris: A. G. Nizet, 1970. 
Art. "Melodie". Dictionnaire de musique. In: Euvres complètes. Vol. V. Paris: Gallimard, 1995.

SCHELLING, F. W. J. Werke. Edição organizada por Manfred Schröter. Munique: Beck, 1992.

Obras Escolhidas. In: "Os Pensadores". Tradução, seleção e notas de Rubens Rodrigues Torres Filho. São Paulo: Abril Cultural, 1979.

Filosofia da arte. Tradução e notas de Márcio Susuki. São Paulo: Edusp, 2001

"Primeiro projeto de um sistema da filosofia da natureza: esboço do todo"; in: Entre Kant e Hegel. Trad. de Joãosinho Beckenkamp. Porto Alegre: EDIPUCRS, 2004.

WANNING, Berbeli. "Schelling". In: Musik in der deutschen Philosophie. Stuttgart: Metzler-Verlag, 2003, p.76-98.

SUSUKI, Márcio. O gênio romântico. São Paulo: Iluminuras, 1998.

TORRES FILHO, Rubens Rodrigues. "O simbólico em Schelling". In: Ensaios de Filosofia Ilustrada. São Paulo: Iluminuras, 2004, p.109-36. 